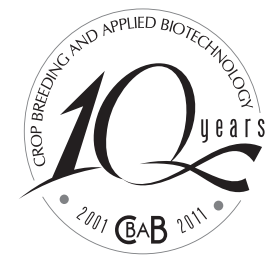

\title{
Analysis of self-fertilization and meiotic behavior of eleven Brazilian triticale cultivars at two sowing dates
}

\author{
Divanilde Guerra $^{1 *}$, Marcelo Teixeira Pacheco ${ }^{1 *}$ and Luiz Carlos Federizzi ${ }^{1}$
}

Received 29 March 2010

Accepted 15 September 2010

\begin{abstract}
Eleven Brazilian hexaploid triticale cultivars $(2 n=6 x=42)$, from three breeding programs, were evaluated for their ability of self-fertilization in 2006 and for meiotic behavior, meiotic index and pollen viability at two sowing dates in 2007. High potential of self-fertilization was observed, with values up to $89.52 \%$. Many irregularities were found in the meiotic analysis, such as the presence of univalents, laggard chromosomes and micronuclei in tetrads, which compromised both meiotic behavior and meiotic index. At the first sowing date, more suitable for normal plant development, overall mean values of $52.68 \%$ for normal cells and $64.95 \%$ for meiotic index were observed. At the second sowing date, less appropriate for the crop, overall means of $52.23 \%$ for normal cells and $58.24 \%$ for meiotic index were obtained. Despite all the irregularities, considerable pollen viability was observed, reaching overall means of $92.08 \%$ and $91.07 \%$ for the first and second sowing dates, respectively.
\end{abstract}

Key words: Triticale; self-fertilization; meiosis; pollen viability.

\section{INTRODUCTION}

In recent decades, intensive crossing has been conducted in the tribe Triticeae aimed at the production of intergeneric hybrids. The first man-made cereal, derived from hybridization between two species of different genera was obtained by the cross between wheat (Triticum spp.), as the maternal parent, and rye (Secale cereale), as the paternal parent, obtaining a hybrid called x Triticosecale Wittmack, commonly known as triticale, as widely used in the literature (Oettler 2005).

This new allopolyploid may have different ploidy levels, being classified into three types: octaploid $(2 n=8 x$ $=56)$, hexaploid (primary and secondary) $(2 \mathrm{n}=6 \mathrm{x}=42)$ and tetraploid $(2 \mathrm{n}=4 \mathrm{x}=28)$ (Gupta and Baum 1986). Tetraploid triticales are agronomically inferior, showing poor protein quality and high sterility (Hohmann 1993), while hexaploids and octaploids have superior agronomic traits. Hexaploids are the most widely cultivated triticales due to their grain yield superiority (Lelley 1992).

Being the result of crossing between wheat, which is an autogamous species, and rye, which is a allogamous species, triticale is considered a self-pollinated plant, with variable levels of outcrossing (Oettler 2005). Triticale has a tendency to allogamy and the percentage of crossfertilization seems to depend on the genotype and environmental conditions (Oettler 2005, Carvalho et al. 2008).

Commercial cropping of this cereal has been expanded throughout the world. In Brazil, triticale research started in 1961 with the introduction of cultivars from Canada and Mexico, due to the resistance to several diseases. However, its development, as a new crop in Brazil, was more effective from 1976 (Baier 2005). The Brazilian

\footnotetext{
${ }^{1}$ Universidade Federal do Rio Grande do Sul (UFRGS), Faculdade de Agronomia, Departamento de Plantas de Lavoura, Av. Bento Gonçalves, 7712, 91.501-970, Porto Alegre, RS, Brazil *E-mail: marpac@ufrgs.br
} 
production of triticale, for many years, was directed to animal feed, due to the color and quality of flour, poorly suited for breadmaking, as well as by the presence of malformed grains (Baier 2005).

Triticale has many advantages such as high protein content, high number of spikes and spikelets per area, resistance to many fungal diseases, among others (Shkutina and Khvostova 1971), however, tends to form shriveled seed and show low fertility. According to Baier (2005), the available germplasm has high yield potential, large spikes with many grains, but the grain filling is still deficient, especially in years with adverse weather conditions, which compromises the crop quality.

Cytological examinations on this cereal in the last decades revealed several meiotic irregularities such as nonpairing of chromosomes, lagging chromosomes, presence of micronuclei, high frequency of aneuploids, partial sterility (Falcão et al. 1981, Hohmann 1993), low fertility and shriveled seed (Oettler 2005). The disorders are associated with many factors like: lack of homology between chromosomes (Singh 1993); duration of the cell cycle (Sisodia and Mcginnis 1970, Lelley 1992); the presence of two chromosome complements of different species (Riley and Chapman 1958) or a genomic shock caused by the fusion of two different genomes in the same allopolyploid nucleus (McClintock 1984). Besides all these abnormalities, Sisodia and Mcginnis (1970) suggested the existence of heritable variation in the meiotic stability of the progeny derived from crosses, affecting their meiotic behavior.

There is a scarcity of studies attempting to analyze the fertility and meiotic stability of Brazilian cultivars of triticale, especially comparing genotypes from different breeding programs and from different years of commercial releases. Therefore, our objectives were: i) to assess the production of seeds per flower through self-fertilization and ii) to evaluate the meiotic behavior, meiotic index and pollen viability of eleven Brazilian triticale cultivars.

\section{MATERIAL AND METHODS}

This study was conducted at the Agronomic Experimental Station (AES) of the Federal University of Rio Grande do Sul (UFRGS), located in Eldorado do Sul, Rio Grande do Sul State (RS) - Brazil, and at the Laboratory of Plant Cytogenetics of the Department of Field Crops (Departamento de Plantas de Lavoura) of the Agronomy School (Faculdade de Agronomia) - UFRGS. The experiments were conducted in 2006 and 2007 with eleven
Brazilian triticale cultivars, commercially released between 1987 and 2005, from the breeding programs of Embrapa (Passo Fundo, RS), Fundacep (Cruz Alta, RS) and IAPAR (Londrina, PR).

\section{Analysis of self-fertilization}

In order to assess the fertility of Brazilian cultivars of triticale, through the ability to exclusively produce seeds by self-fertilization, a field experiment was established at the AES/UFRGS in 2006 with eleven triticale cultivars (Table 1). The experimental units consisted of two 3-meter long rows, with 10 seeds sown in each row. The space between plants and between rows was $0.30 \mathrm{~m}$. Each treatment consisted of three replications. To evaluate the spike fertility, the main spike of each plant, at the pre-anthesis, was protected from cross-fertilization with parchment paper (butter paper) bags. Since triticale has long awns, which will tear the paper bags when fully developed, the awns from each spike were clipped before protection. At maturity, the protected spikes were harvested and those with nontorn paper bags had the number of flowers and number of seeds counted, in order to estimate the degree of selffertilization. The spike fertility was considered as the percentage of seeds produced in relation to the total number of flowers counted in each spike. Statistical analyses were performed using SAS software (SAS 1989).

\section{Meiotic behavior}

In 2007, the same 11 cultivars of triticale were sown in the field on August $3^{\text {rd }}$ and $27^{\text {th }}$, which are called first and second sowing dates in this paper. Each plot consisted of two rows, as described for the previous year.

For meiotic analysis young spikes at different phases of the booting stage were collected, at both first and second sowing dates. The collected spikes were fixed in a solution of alcohol and glacial acetic acid at a ratio of 3:1, right after being taken out of the plants. Six to eight hours after collection, the solution of alcohol and glacial acetic acid was replaced by a new solution to remove the excess of released chlorophyll, and maintained so for 24 hours at room temperature. Afterward, the spikes were stored in a $70 \%$ alcohol solution in a freezer. For the analysis, anthers were cut, macerated and stained with $2 \%$ propionic carmine on a glass slide. Assessment of meiotic behavior was performed by evaluating all possible pollen mother cells (PMC) on each slide, and at all stages of meiosis. When the cells had all their chromosomes in bivalent associations they were considered normal and the cells 
presenting univalents, trivalents, quadrivalents or multiple unidentified chromosome associations were considered as irregular cells. The presence of chromosome bridges was also recorded. The meiotic index was calculated by dividing the number of normal tetrads by the total number of tetrads observed, this value multiplied by 100 , as suggested by Löve (1949). The tetrads were considered normal when they presented four microspores of equal size and without the presence of micronuclei, and those tetrads with a number of microspore different than four, with different sizes, or with the presence of micronuclei were regarded as abnormal. Two glass slides per individual and all the cells present in each slide were evaluated for estimation of meiotic index. Pollen viability was estimated by the pollen ability to stain with propionic carmine, evaluating three glass slides per plant and counting 200 pollen grains per slide, randomly, adding a total of 600 grains. The pollen grains were considered viable when were well stained and considered unviable when were empty or colorless.

\section{RESULTS AND DISCUSSION}

\section{Self-fertilization analysis}

In the analysis for determining the fertility of triticale cultivars, through the ability of self-fertilization, there were differences in the number of spikes evaluated, which ranged from 4 (Iapar54-Ocepar 4) to 30 spikes (Fundacep 48) (Table 1). This variation was due to the different number of spikes that remained protected against cross-fertilization from pre-anthesis to maturity and harvest, especially because of strong winds and rains during this period.

The percentage of seed production per flower, on the mean of each cultivar, ranged from 40 to $69.71 \%$, indicating good ability of self-pollination (Table 1). However, a wide variation was observed for the minimum value of seeds per flower. The cultivars Embrapa 53, BRS 148, BRS Minotauro and Iapar 38 - Araruna had some spikes with no seed production, affecting their means. Nevertheless, when analyzing the maximum percentage values of seeds per flower, it was observed that all cultivars reached high values, all above $72.0 \%$ (Table 1). Field observations allow us to state that the absence of seed production in some spikes were due to the influence of biotic and abiotic stresses. In this way, the hypothesis of inability of selfpollination can be discarded, since the maximum values of spike fertility were high, with an overall mean of $80.38 \%$. The results showed that all cultivars have good ability of self-fertilization, reaching values up to $89.52 \%$, as observed in the cultivar CEP 28 - Guará. These results are consistent with data obtained by Gülmezoglu (2004) who observed percentages of seed production by self-fertilization from 65.36 to $81.80 \%$ in the evaluation of four triticale genotypes. Considering the possible stresses to which the spikes of triticale were submitted, due to protection with butter-paper bags, the values of self-fertilization were high. Under natural conditions (unprotected spikes), the values of spike fertility could have been higher.

Considering the mean values of spike fertility for the triticale cultivars developed by each breeding program, the mean spike fertility was lower for cultivars developed by Embrapa, compared to the cultivars developed by Fundacep or IAPAR (Table 1). Taking the average of maximum values of spike fertility, within each breeding program, a greater potential for self-fertilization is found for the cultivars developed by Fundacep, although this comparison is weakened by the fact that only two cultivars from this breeding program were evaluated (Table 1). The year of release of each cultivar was not associated with the ability of self-fertilization (Table 1), considering all 11 cultivars (analysis not shown), and this is possibly related to the different ability of self-fertilization of the genotypes used in the crosses that originated these cultivars.

\section{Meiotic behavior}

The chromosome number of the eleven triticale cultivar was determined as $n=21$, according to the performed meiotic analysis (Figure 1a), confirming that all are hexaploid $(2 n=6 x=42)$. Analysis of meiotic behavior showed a high presence of cells with abnormalities (Figure 1, Tables 2 and 3). Irregularities were observed as laggard chromosomes in anaphase I (Figure 1b), micronuclei in telophase I (Figure 1c) and telophase II (Fig. 1d), normal tetrad and tetrad with micronuclei (Figure 1e), and unviable pollen (Figure 1f).

Many irregularities were observed in this study and these can be related to several factors. Thomas and Kaltsikes (1974) attributed the reduced pairing of the rye chromosomes, relative to wheat chromosomes in triticale, to the greater amount of heterochromatin in the rye chromosomes. On the other hand, Fominaya and Orellana (1988) found no relationship between the amount of heterochromatin in the rye chromosomes and reduction of pairing of chromosomes in octaploid triticales. However, to Merker (1971) heterochromatin is not the only factor responsible for the presence of univalents, but rather a combination of several factors. 


\begin{tabular}{|c|c|c|c|c|c|c|c|c|c|c|}
\hline Genotype & $\begin{array}{c}\text { Year of } \\
\text { Crossing }\end{array}$ & Origin & $\begin{array}{c}\text { Year of } \\
\text { Introduction }\end{array}$ & $\begin{array}{c}\text { Year of } \\
\text { Release* }^{*}\end{array}$ & $\begin{array}{l}\text { Breeding } \\
\text { Program }\end{array}$ & Mean & Minimum & Maximum & $\begin{array}{l}\text { Standard } \\
\text { Deviation }\end{array}$ & $\begin{array}{c}\text { Number of } \\
\text { Spikes }\end{array}$ \\
\hline Triticale BR 4 & - & México & - & 1990 & Embrapa - RS & 51.42 & 15.96 & 74.56 & 14.59 & 14 \\
\hline Embrapa 53 & 1984 & México & - & 1996 & Embrapa - RS & 61.13 & 0.00 & 80.00 & 18.46 & 29 \\
\hline BRS 148 & 1984 & México & - & 1998 & Embrapa - RS & 64.85 & 0.00 & 77.97 & 19.00 & 16 \\
\hline BRS 203 & 1984 & México & 1990 & 2000 & Embrapa - RS & 40.86 & 3.86 & 74.14 & 25.19 & 14 \\
\hline BRS Minotauro & 1991 & Brasil & - & 2005 & Embrapa - RS & 65.19 & 0.00 & 83.84 & 17.62 & 20 \\
\hline Embrapa mean & & & & & & 56.69 & 3.96 & 78.10 & 18.97 & 18.6 \\
\hline CEP 28 - Guará & - & México & 1990 & 1996 & Fundacep -RS & 67.05 & 37.96 & 89.52 & 12.25 & 24 \\
\hline Fundacep 48 & 1989 & México & 1996 & 2004 & Fundacep -RS & 62.78 & 2.13 & 84.26 & 17.63 & 30 \\
\hline Fundacep mean & & & & & & 64.91 & 20.04 & 86.89 & 14.94 & 27.0 \\
\hline Iapar23 - Arapoti & 1984 & México & - & 1987 & IAPAR - PR & 68.35 & 53.40 & 83.50 & 7.31 & 20 \\
\hline Iapar38 - Araruna & 1984 & México & - & 1989 & IAPAR - PR & 65.33 & 0.00 & 86.15 & 17.85 & 19 \\
\hline Iapar54-Ocepar 4 & 1986 & México & - & 1992 & IAPAR - PR & 69.71 & 65.63 & 78.26 & 5.78 & 4 \\
\hline IPR 111 & 1989 & México & 1996 & 2003 & IAPAR - PR & 54.32 & 31.91 & 72.00 & 10.33 & 24 \\
\hline IAPAR mean & & & & & & 64.43 & 37.73 & 79.98 & 10.32 & 16.75 \\
\hline Overall mean & & & & & & 61.00 & 19.17 & 80.38 & 15.09 & 19.45 \\
\hline
\end{tabular}


D Guerra et al.

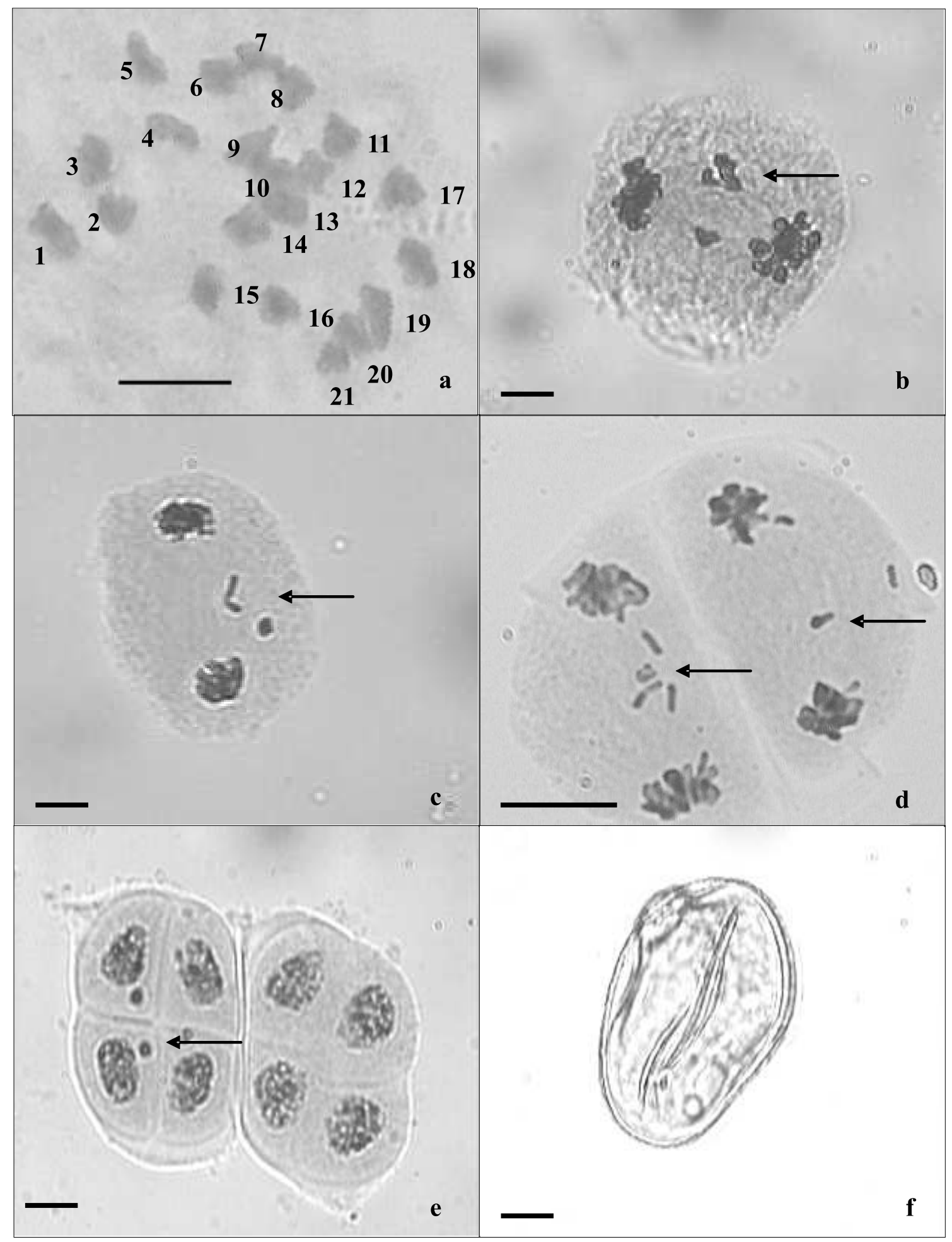

Figure 1 - Meiosis. a) Metaphase I with 21 bivalents in BRS Minotauro; b) Anaphase I with laggard chromosomes (arrow) in Iapar23Arapoti; c) Telophase I with laggard chromosomes (arrow) in Iapar23 Arapoti; d) Telophase II with laggard chromosomes (arrow) in Embrapa 23; e) Regular Tetrad and tetrad with micronuclei (arrow) in BRS Minotauro; f) unviable pollen grain in Iapar54-Ocepar 4. Scale $10 \mathrm{~mm}$. 
Table 2. Meiotic analysis, meiotic index and pollen fertility of eleven Brazilian triticale cultivars sown in the field on August $3^{\text {rd }}$ of 2007

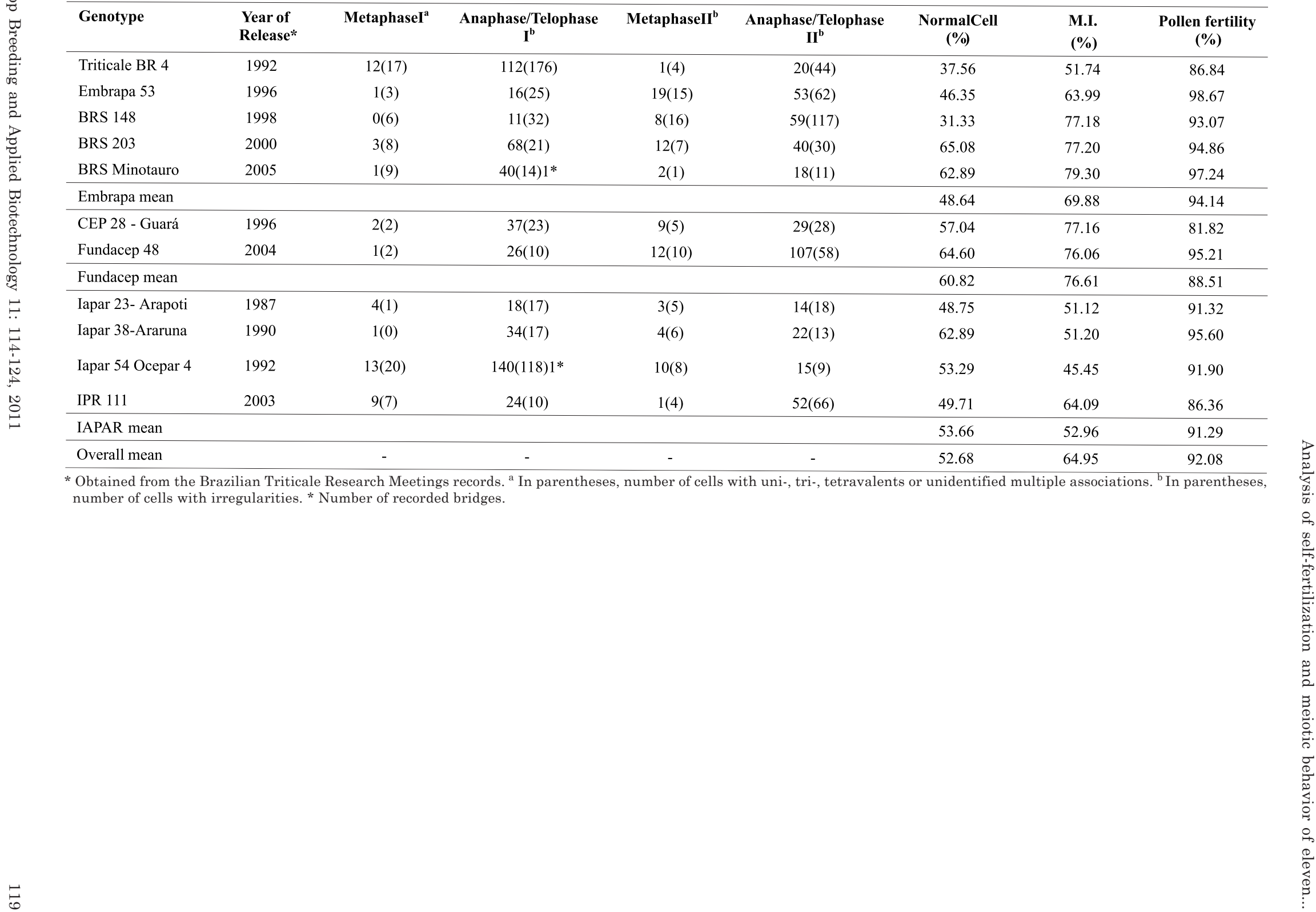


Table 3. Meiotic analysis, meiotic index and pollen fertility of eleven Brazilian triticale cultivars sown in the field on August $27^{\text {th }}$ of 2007

\begin{tabular}{|c|c|c|c|c|c|c|c|c|}
\hline Genotype & $\begin{array}{c}\text { Year of } \\
\text { Release * }\end{array}$ & $\begin{array}{c}\text { Metaphase } \\
\text { I }^{\text {a }}\end{array}$ & $\begin{array}{l}\text { Anaphase/ } \\
\text { Telophase } I^{b}\end{array}$ & $\begin{array}{c}\text { Metaphase } \\
\text { II }^{\mathbf{b}}\end{array}$ & $\begin{array}{c}\text { Anaphase/ } \\
\text { Telophase II }^{\mathbf{b}}\end{array}$ & $\begin{array}{l}\text { Normal } \\
\text { Cell (\%) }\end{array}$ & $\begin{array}{l}\text { M.I. } \\
(\%)\end{array}$ & $\begin{array}{c}\text { Pollen fertility } \\
(\%)\end{array}$ \\
\hline Triticale BR 4 & 1992 & $3(5)$ & $56(66) 1^{*}$ & $3(2)$ & $12(20)$ & 44.05 & 54.04 & 83.81 \\
\hline Embrapa 53 & 1996 & $0(0)$ & $18(20)$ & $14(14)$ & $118(117)$ & 49.83 & 55.72 & 96.36 \\
\hline BRS 148 & 1998 & $16(14)$ & $136(70) 1^{*}$ & $6(18)$ & $61(31)$ & 62.22 & 60.89 & 92.56 \\
\hline BRS 203 & 2000 & $10(7)$ & $47(34)$ & $9(7)$ & $53(49)$ & 55.09 & 68.37 & 94.68 \\
\hline BRS Minotauro & 2005 & $2(0)$ & $20(28)$ & $12(14)$ & $74(96)$ & 43.90 & 53.82 & 95.40 \\
\hline Embrapa mean & & & & & & 51.02 & 58.57 & 92.56 \\
\hline CEP 28 - Guará & 1996 & $2(12)$ & $74(38)$ & $6(4)$ & $12(3)$ & 65.25 & 66.51 & 80.03 \\
\hline Fundacep 48 & 2004 & 4(9) & $25(18)$ & $20(16)$ & $76(63)$ & 54.11 & 67.28 & 96.03 \\
\hline Fundacep mean & & & & & & 59.68 & 66.89 & 88.03 \\
\hline Iapar 23- Arapoti & 1987 & $6(11)$ & $25(35)$ & $13(16)$ & $53(63)$ & 43.69 & 52.46 & 90.67 \\
\hline Iapar 38-Araruna & 1990 & $1(3)$ & $19(17)$ & $9(10)$ & $49(45)$ & 50.98 & 52.63 & 90.50 \\
\hline Iapar 54 Ocepar 4 & 1992 & $2(5)$ & $61(53)$ & $17(12)$ & $29(26)$ & 53.17 & 50.68 & 90.69 \\
\hline IPR 111 & 2003 & $3(6)$ & $110(148)$ & $5(12)$ & $26(24)$ & 43.11 & 69.33 & 85.46 \\
\hline IAPAR mean & & & & & & 47.74 & 56.27 & 89.33 \\
\hline Overall mean & & - & - & - & - & 52.23 & 58.24 & 91.07 \\
\hline
\end{tabular}

(the Brazilian Triticale Research Meetings records. "In parentheses, number of cells with uni-, tri-, tetravalents or unidentified multiple associations.

${ }^{\mathrm{b}}$ In parentheses, number of cells with irregularities. * Number of recorded bridges. 
Fails in chromosome pairing by the absence chromosome homology and the presence of two genomic complements the same nucleus can influence the irregularities observed in triticale. According to Singh (1993), the lack of homology between chromosomes causes numerous abnormalities in the cells. And for Mcclintock (1984) a genomic shock may occur in intergeneric hybrids, caused by the fusion of two different genomes in the same allopolyploid nucleus, which would lead to meiotic abnormalities. Some authors suggest that failure in chromosome pairing and the presence of univalents are associated exclusively with rye chromosomes (Jung et al. 1985), but Larter and Shigenaga (1971) showed that both wheat and rye chromosomes may show as univalents. The cell cycle duration may also act in the irregularities observed in triticale. According Sisodia and Mcginnis (1970) and Lelley (1992), differences in the meiotic cycle of two parents generate irregularities in this species, as the presence of univalents.

In this study, given that commercial triticale cultivars were analyzed, satisfactory rates of meiotic stability were expected, because the genotypes were selected for increased grain yield over the years, and the two traits could be correlated, but this was not observed. Sisodia and Mcginnis (1970) suggested the existence of heritable variation in the meiotic stability of the progeny. This was confirmed by Falcão et al. (1981) who found high and significant correlations between parents and their progeny for traits such as the presence of univalents, laggard chromosomes and micronuclei in tetrads. Thus, one can infer that there is heritable variation for the meiotic behavior and that the genotypes used in the crosses of these cultivars might not have satisfactory meiotic behavior. Under this assumption and considering the high presence of irregularities in the triticale cultivars analyzed, the adoption of assisted selection of parents with superior meiotic behavior in breeding programs of triticale through cytological techniques can be suggested. At first, this type of assisted selection would be especially useful for the elimination of parents with high meiotic instability from the crossing blocks.

For the meiotic analysis at the first sowing date (August $3^{\text {rd }}$, 2007) the cultivars showed an overall mean of $52.68 \%$ for normal cells, $64.95 \%$ for the meiotic index and $92.08 \%$ for the viability of pollen grains (Table 2). While at the second sowing date (August 27th 2007) there was little decrease in overall means of normal cells and pollen fertility, $52.23 \%$ and $91.07 \%$ respectively. However, a greater reduction was observed in the meiotic index, $58.24 \%$ (Table 3 ). The low meiotic index in two sowing dates, compared to the considerable pollen viability, may be associated with the presence of micronuclei in the microspores as observed in the meiotic index analysis. A possible elimination of these micronuclei in the stages preceding pollen grain formation will affect the outcome, ensuring more satisfactory results for pollen viability. Sampling errors may also have contributed to the observed results. Nevertheless, the meiotic index of $64.95 \%$ in the first sowing date and $58.24 \%$ in the second one are well below the value proposed by Löve (1949), who suggested that only plants with a meiotic index above $90 \%$ can be considered cytologically stable and therefore likely to be part of a breeding program.

The behavioral differences between the first and second sowing dates can also be observed in the averages of cultivars released by the three breeding programs, except for the mean percentage of normal cells in the meiosis of cultivars developed by Embrapa and Fundacep (Tables 2 and 3). Even though the normal cells mean of the two cultivars developed by Fundacep was lower at the second sowing date, the cultivar Cep 28 - Guará had a lower percentage of normal cells in the meiosis at the first sowing date $(57.04 \%)$, compared to the second one $(65.25 \%)$. When Embrapa cultivars are examined one by one, it can be observed that BRS 148 presented only $31.33 \%$ of the normal cells in the meiosis at the first sowing date, compared to $62.22 \%$ at second sowing date. This anomalous behavior may come from the small number of cells found in metaphase I and II and anaphase/telophase I for this genotype at the first sowing date. Considering this as an artifact and removing the BRS 148 from the analysis, cultivars from Embrapa showed $52.97 \%$ for the mean percentage of normal cells in meiosis at the first sowing date, compared to $48.22 \%$ at the second one.

The meiotic analysis differences between sowing dates may possibly be linked to the fact that the first sowing date was more appropriate for triticale growth under Southern Brazil climatic conditions. According to the 2005/2006 Triticale Management Guide released by the South Brazilian Wheat and Triticale Research Commission, the best window to sow triticale in Eldorado do Sul - RS is from the second half of May to the second half of June and, therefore, the first sowing date is closest to the time window proposed for triticale cultivation. The differences observed in this study with respect to sowing date are consistent with the work of Sisodia and Mcginnis (1970), 
who found varying levels of meiotic instability in triticale genotypes sown at different dates. According to Sato et al. (2002), in many species the reproductive stage is more sensitive to abiotic stresses than the vegetative stage. Saini et al. (1997) considered the meiotic stage as the most sensitive period in the life cycle of seed plants. Thus, the weather conditions during the reproductive stage at the first sowing date may have been more favorable than the ones which occurred at the second sowing date.

Laggard chromosomes and micronuclei in tetrads were observed in high frequencies in this study (Tables 2 and 3). According to Bodanese-Zanettini et al. (1983) weather changes, especially in temperature, have a strong influence on the appearance of these irregularities. There are many environmental factors that can lead to abnormalities during meiosis, such as temperature, nutrient levels, water availability, light, salinity and pollution (Sun et al. 2004). At least some of these factors may have played a role in the observed difference between the two sowing dates.

Pollen fertility at the first sowing date had a mean of $92.08 \%$ and at the second date it was a little lower, reaching $91.07 \%$ (Tables 2 and 3). Different environmental factors may have influenced the results. Morgan (1980), studying wheat under water stress during meiosis, observed male sporogenesis impairment and pollen inviability. Jäger et al. (2008) also observed meiotic abnormalities and reduced pollen viability in wheat under water and temperature stresses.

Comparing the cultivars developed by the three different breeding programs one can find that, on average, cultivars developed by Fundacep had higher meiotic stability but lower pollen fertility, both at the first and second sowing dates. This lower pollen fertility of the Fundacep cultivars is a result of low pollen fertility observed in cultivar CEP 28 - Guará, released in 1996. Analyzing the 11 cultivars altogether, and not considering the percentage of normal cells in meiosis of BRS 148, a positive correlation $(0.57)$ between the percentage of normal cells and meiotic index was observed at the first sowing date, although significance was only 0.087 . No association between percentage of normal cells or meiotic index with pollen fertility was found (analyses not shown). The reason for this lack of association cannot be directly identified, but these results may be related to sampling errors or due to a possible elimination of micronuclei in the microspores, a mechanism described by BaptistaGiacomelli et al. (2000) in Avena sativa.
Considering the year of release (Table 1) an improvement trend in the meiotic index and pollen viability can be observed for the latest released cultivars (Tables 2 and 3), which may be associated with selection for higher grain yield, resulting in indirect selection for higher meiotic index and pollen fertility. As an example, BRS Minotauro, developed in Brazil (Nascimento Junior et al. 2008), showed the highest pollen fertility at the first sowing date. BRS Minotauro, besides being the most recently released cultivar, was developed and selected under the climatic conditions of Southern Brazil, while the others originated were and selected in Mexico, where climatic conditions are different from those found in Brazil.

Correlation between the viability of pollen and spike fertility was almost zero (0.02) at the first sowing date. At the second sowing date a significant positive correlation, although low $(0.16 \%)$, was found between the percentage of normal cells and spike fertility. Aiming to analyze the correlation between meiotic behavior and spike fertility in triticale, Pieritz (1966) found a significant positive correlation between the percentage of normal cells and fertility in octaploid triticales. Falcão et al. (1981) observed a significant positive correlation between the meiotic regularity and fertility also in triticale, but found no correlation between meiotic index and fertility. Nevertheless, Weimarck (1973) observed no correlation between fertility and the presence of univalents in triticale. According to Moraes-Fernandes (1982), many studies have been developed to verify possible associations between seed fertility and meiotic abnormalities, however many of them present conflicting results, given that it is difficult to observe the relationship between seed fertility and chromosomal aberrations, because there are many genetic and environmental factors involved in the process, from fertilization to seed maturity.

Analyses of meiotic behavior of the cultivars revealed that even with all the selection progress already made in triticale many irregularities are still observed. However, viable pollen production was considerable, ensuring a high potential of self-fertilization.

\section{ACKNOWLEDGEMENTS}

To CNPq (National Council for Scientific and Technological Development) for a scholarship awarded to the first author.

Crop Breeding and Applied Biotechnology 11: 114-124, 2011 


\title{
Análise da autofertilização e do comportamento meiótico de onze cultivares de triticale semeadas em duas épocas
}

\begin{abstract}
RESUMO - Onze cultivares brasileiras de triticale hexaplóide $(2 n=6 x=42)$, oriundas de três programas de melhoramento genético foram avaliadas quanto à capacidade de autofertilização em 2006 e quanto ao comportamento meiótico, índice meiótico e viabilidade dos grãos de pólen em duas épocas de semeadura, em 2007. As análises permitiram observar alto potencial de autofertilização com valores de até 89,52\%. Nas análises meióticas foram observadas muitas irregularidades, como presença de univalentes, cromossomos retardatários e micronúcleos em tétrades, que comprometeram o comportamento e o índice meiótico. Na primeira época de semeadura, mais adequada ao desenvolvimento da cultura, observou-se valores de 52,68 \% de células normais e 64,95\% de índice meiótico. Na segunda época, fora do período mais adequado, foram obtidos 52,23\% de células normais e $58,24 \%$ de índice meiótico. Apesar de todas as irregularidades, considerável viabilidade de pólen foi observada, com 92,08 \% e 91,07\%, para a primeira e segunda época, respectivamente.
\end{abstract}

Palavras-chave: Triticale; autofertilização; meiose; viabilidade do pólen.

\section{REFERENCES}

Baier AC (2005) Melhoramento do triticale. In Borém A (ed.) Melhoramento de espécies cultivadas. Editora UFV, Viçosa, p. 699-715.

Baptista-Giacomelli FR, Pagliarini MS and Almeida JL (2000) Elimination of micronuclei from microspores in a Brazilian oat (Avena sativa L.) variety. Genetics and Molecular Biology 23: 681-684.

Bodanese-Zanettini MH, Moraes-Fernandes MIB and Salzano FM (1983) Genetic and environmental effects on the frequency of meiotic disturbances in wheat. Genetics and Molecular Biology 6: 43-57.

Carvalho FIF, Nascimento Junior A and Piana CFB (2008) Triticale. In Barbieri RL and Stumpf RT (eds.) Origem e evolução de plantas cultivadas. Editora Embrapa, Brasília, p. 853-890.

Falcão TMMA, Moraes-Fernandes MIB and Bodanese-Zanettini MH (1981) Genotypic and environmental effect on meiotic behavior and the influence of chromosomal abnormalities on fertility of hexaploid triticale (X Triticosecale Wittmack). Revista Brasileira de Genética 4: 611-624.

Fominaya A and Orellana J (1988) Does differential Cheterochromatin content affect chromosome pairing in octoploid triticale? Heredity 61: 167-173.

Gülmezoglu N (2004) Spontaneous cross pollination studies on Triticale (X Triticosecale Wittmack) Genotypes. Pakistan Journal of Biological Sciences 7: 1164-1167.

Gupta PK and Baum BR (1986) Nomenclature and related taxonomic issues in wheats, triticales and some of their wild relatives. Taxon 35: 144-149.
Hohmann U (1993) Stabilization of tetraploid triticale with chromosomes from Triticum aestivum $(\mathrm{ABD})(\mathrm{ABD}) \mathrm{RR}(2 \mathrm{n}=$ 28). Theoretical and Applied Genetics 86: 356-364.

Jäger K, Fábian A and Barnabás B (2008) Effect of water deficit and elevated temperature on pollen development of drought sensitive and tolerant winter wheat (Triticum aestivum L.) genotypes. Acta Biologica Szegediensis 52: 67-71.

Jung C, Lelley T and Belen G (1985) Genetic interactions between wheat and rye genomes in triticale. Theoretical and Applied Genetics 70: $422-426$.

Larter EN and Shigenaga S (1971) Further evidence on the derivation of univalents in hexaplóide triticale. Canadian Journal of Genetics and Cytology 13: 895-898.

Lelley T (1992) Triticale, still a promise? Plant Breeding 109: $1-17$.

Löve RM (1949) Estudos citológicos preliminares de trigos rio-grandenses. Secretaria do Estado dos Negócios da Agricultura, Indústria e Comércio, Porto Alegre, 23p. (Circular 74).

Merker A (1971) Cytogenetic investigations in hexaplóide Triticale. I. Meiosis, aneuploidy and fertility. Hereditas 68: 281-290.

McClintock B (1984) The significance of responses of the genome to challenge. Science 226: 792-801.

Moraes-Fernandes MIB (1982) Estudo da instabilidade meiótica em cultivares de trigo: efeito genotípico, relação com a fertilidade e seleção de plantas estáveis. Pesquisa Agropecuária Brasileira 17: 1177-1191. 
D Guerra et al.

Morgan JM (1980) Possible role of abscisic acid in reducing seed set in water-stressed wheat plants. Nature 285: 655-657.

Nascimento Junior A, Scheeren PL, Silva MS, Caierão E, Eichelberger L, Lima MIPM, Brammer SP and Albuquerque ACS (2008) BRS Minotauro - Triticale Cultivar. Crop Breeding and Applied Biotechnology 8: 174-176.

Oettler G (2005) The fortune of a botanical curiosity - triticale: past, present and future. Journal of Agricultural Science 5: 329-346.

Pieritz WJ (1966) Untersuchungen über die Ursachen der aneuploidie bei amphidiploiden Weizen-Roggen-Bastarden und über die Funktionsfähigkeit ihrer männlichen und weiblichen Gameten. Zeitschrift für Pflanzenzüchtung 56: 27-69.

Riley R and Chapman Y (1958) Genetic control of the cytological diploid behavior of hexaplóide wheat. Nature 182: 713-715.

Saini HS (1997) Effects of water stress on male gametophyte development in plants. Sexual Plant Reproduction 10: $67-$ 73.

SAS (1989) SAS/STAT; user's guide: version 6.4. SAS, Cary, 846 p.
Sato S, Peet MMA and Thomas JF (2002) Determining critical pre- and post-anthesis periods and physiological processes in Lycopersicum esculentum Mill. exposed to moderately elevated temperature. Journal of Experimental Botany 53: 11871195 .

Shkutina FM and Khvostova VV (1971) Cytological investigation of triticale. Theoretical and Applied Genetics 41: 109119.

Singh RJ (1993) Plant cytogenetics. CRC Press, Florida, 391p.

Sisodia NS and Mcginnis RC (1970) Importance of hexaploid wheat germoplasm in hexaploid triticale breeding. Crop Science 10: $161-162$.

Sun K, Hunt K and Hauser BA (2004) Ovule abortion in Arabidopsis triggered by stress. Plant Physiology 135: 2358-2367.

Thomas JB and Kaltsikes PJ (1974) A possible effect of heterochromatin on chromosome pairing. Proceedings of the National Academy of Sciences 71: 2787-2790.

Weimarck A (1973) Cytogenetic behaviour in octoploid Triticale. I. Meiosis, aneuploidy and fertility. Hereditas 74: 103-118. 